\title{
62. ZEOLITE FACIES METAMORPHISM, GEOCHEMISTRY, AND SOME ASPECTS OF TRACE ELEMENT REDISTRIBUTION IN ALTERED BASALTS OF DSDP, LEG 37
}

\author{
A.J. Andrews, R.L. Barnett, B.A.E. MacClement, W.S. Fyfe, G. Morrison, N.D. MacRae, \\ and John Starkey, University of Western Ontario London, Ontario, Canada
}

\begin{abstract}
Oxidation and hydration of DSDP Leg 37 basalts occur within, and immediately adjacent to channelways such as cracks, vesicles, and breccias and are a consequence of the movement of fluids, most likely seawater, through such permeable areas. There is no evidence to suggest an increase in grade with depth. Alteration is uniform, never exceeds zeolite grade, and has involved the generation of clay minerals, mainly potassium-rich saponite and zeolites, mainly phillipsite. Prehnite occurs in one sample of gabbro breccia which has experienced rather intense hydrothermal alteration. Electron microprobe analysis of zoned saponite in vesicles reveals a gradual transition from green $\mathrm{Fe}$ rich- $\mathrm{Mg}$ poor saponite in the rim to colorless or black $\mathrm{Mg}$ rich-Fe poor saponite in the core.

Oxidation halos are commonly 10-15 times and up to 20 times the width of associated cracks and veins. Veins characteristically contain clastic carbonate and foraminiferal tests sluiced in from the ocean floor, and highly altered fragments of wall rock, which in one specimen, contain native copper.

Spark source mass spectrometric analysis of fresh basalt and oxidized material from adjacent to veins suggests that, with the possible exception of $\mathrm{Mn}$, the distributions of $\mathrm{Ti}, \mathrm{Ni}, \mathrm{Co}, \mathrm{Cu}, \mathrm{Zn}$, and $\mathrm{Sr}$ are not much affected by interaction with low temperature, permeating seawater.
\end{abstract}

\section{INTRODUCTION}

This chapter presents a detailed study on the mineralogical and chemical characteristics of altered submarine basalts of Leg 37. Special emphasis is given to clay minerals which are the most abundant alteration products observed in this study and which have received little attention previously. We also focus on some aspects of trace element redistribution as a result of interaction between low-temperature seawater and basalt.

A. Andrews prepared the main body of this report, and he is also responsible for detailed mineralogy on selected samples and trace element determinations by spark source mass spectroscopy. B. MacClement is responsible for all X-ray mineralogy, while R.D. Barnett conducted major element analyses by electron microprobe. G. Morrison conducted extensive optical mineralogy on a large number of samples.

\section{ANALYTICAL METHODS}

Chemical analyses of clay minerals were measured by electron microprobe. From three selected samples, 28 nine-element analyses were conducted on zoned clay minerals occurring in vesicles and the groundmass. Electron microprobe analysis of clay minerals may be complicated by the following conditions: (1) clay minerals are often extremely fine grained, (2) they are often grossly inhomogeneous, and (3) they decompose readily under the electron beam. In spite of these poten- tial difficulties, analyses cited in this report exhibit satisfactory internal consistency and acceptable homogeneity indices (Appendix A).

$\mathrm{X}$-ray diffraction powder patterns were all measured by a one-radian Gandolfi camera (Gandolfi, 1967).

Trace elements and $\mathrm{Ti}$ were measured by a JEOL model JMS-01BM-2 spark source mass spectrometer and line spectra were analyzed by a Joyce MK III C double-beam recording microdensitometer. Concentrations were calculated using a procedure adapted from Owens (1966) and Ahrens and Taylor (1961).

A total of 80 samples was studied from material recovered at all sites of Leg 37 . Forty samples selected mainly from Holes $332 \mathrm{~A}$ and $332 \mathrm{~B}$ were studied in thin section.

\section{ALTERATION MINERALOGY}

\section{General Statements}

1) For the most part, alteration is low grade involving the generation of clay minerals (mainly smectites) and zeolites (mainly phillipsite). Although many samples exhibit some degree of smectite generation in the groundmass, alteration is concentrated primarily within and adjacent to open spaces such as cracks, vesicles, veins, and breccias. Primary phases do not show well-developed alteration, except when situated within oxidized halos adjacent to channelways which have been accessible to fluids. The main process of 
alteration appears to have involved the percolation of seawater through permeable areas. Table 1 summarizes the occurrence of the major secondary phases developed in particular environments.

2) In the specimens studied there is no evidence to suggest an increase in metamorphic grade with depth. Alteration is uniform and never exceeds zeolite grade. Exceptions to this are Samples 334-24-2, 30-36 cm and 334-24-3, 139-142 cm, coarse-grained gabbro breccias which exhibit intense hydrothermal alteration. These rocks consist of coarse-grained gabbro fragments and xenocrysts of altered plagioclase and pyroxene in a finely crushed matrix. Table 2 lists the secondary phases identified together with simplified metamorphic reactions interpreted from textural relationships.

Textures and secondary minerals indicate that these rocks have experienced intense hydration, brecciation, and probably mylonitization, a situation most likely due to faulting and localization of hydrothermal fluids (seawater or magmatic water) along structural breaks.

3) Relative to plagioclase and pyroxene, olivine is the primary phase most susceptible to alteration and when situated within oxidized halos around cracks and veins displays either partial or complete alteration to saponite, calcite, and occasionally iddingsite. Pseudomorphed olivines displaying hematite rims are also quite common (Plate 1). Plagioclase seems quite resistant to alteration, but does in many cases exhibit limited development of phillipsite (Plate 2) and to a lesser extent smectite (Plate 3).

No well-developed alteration of pyroxene is observed in the samples studied, but this may be due, in part, to the fact that pyroxene phenocrysts are quite rare and as a result, alteration would not be as conspicuous as that of olivine and plagioclase. It is conceivable, although not texturally confirmed, that smectite (saponite-nontronite) sometimes observed in oxidized groundmass is an alteration product of pyroxene occurring in the groundmass.

4) While a variety of minerals occur as vesicle linings and amygdule fillings (Table 1), clay minerals and calcite are by far the most common. Calcite is the most common vesicle filling in relatively fresh rock, whereas clay minerals are more common in oxidized areas. Within a single sample, changes from one type to the other are often quite abrupt (within millimeters), particularly at the interface between oxidized and unoxidized material).

Amygdules sometimes exhibit systematic mineralogical changes with distance from a crack or vein and the oxidation halo associated with it. An example of this occurs in Sample 332B-37-2, 18-20 cm, and is illustrated in Figure 1. Such changes reflect an environment which was decreasingly oxidizing with increasing distance from the vein.

Vesicles containing clay minerals commonly exhibit complex zoning, a condition which will be discussed together with chemical data below. A large elliptical vesicle (long diameter $2 \mathrm{~cm}$ ) occurs in Sample 332A-12$1,93-96 \mathrm{~cm}$, which displays an extremely fine grained greenish-blue lining. Examination of this lining with a scanning electron microscope revealed an interesting mineralogy and structure, as follows: (1) welldeveloped pyrite cubes attached to the vesicle wall, (2) a layer of smectite (saponite-nontronite) covering the pyrite crystals, and (3) framboidal spheres of pyrite growing from the surface of the smectite (Plate 4). The smectite is extremely fine grained and at a magnification of $1000 \times$ appears as a web-like intergrowth (Plate 5). Examination at $3000 \times$ reveals that the fundamental particles are extremely thin platelets which are irregular in outline (Plate 6).

The occurrence and detailed structure of the pyrite framboids are not comparable to sulphide spherules commonly observed in similar environments. The latter occur in vesicles of ocean-floor basalt as smoothsurfaced spheres often partly embedded in glass rims and are interpreted as syngenetic features resulting from extremely rapid cooling (Moore and Galk, 1971). The forms observed here are more comparable in structure to marcasite framboids described from sedimentary environments (Love, 1964), in that they are comprised of a closely packed aggregation of small individual grains. The pyrite framboids in Section 332A-

TABLE 1

Occurrence and Relative Abundance of Secondary Minerals, Volcanic Rocks, DSDP Leg 37

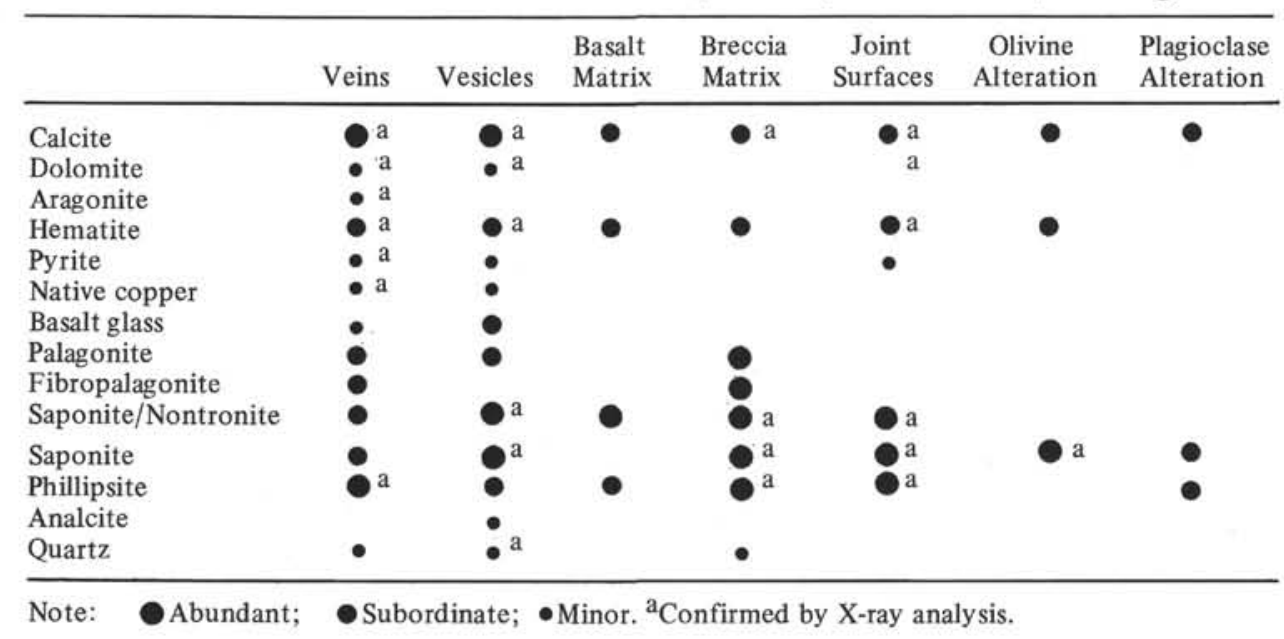


TABLE 2

Secondary Minerals in Gabbro Breccia, Samples 334-24-2, 30-36 cm, and $334-24-2,139-142 \mathrm{~cm}$

\begin{tabular}{|c|c|}
\hline Orthopyroxene & $\begin{array}{l}\text { amphibole } \\
\text { bastite } \\
\text { chlorite (perininite) } \\
\text { talc (minor) }\end{array}$ \\
\hline Clinopyroxene & actinolite-tremolite \\
\hline $\begin{array}{l}\text { Olivine and } \\
\text { orthopyroxene }\end{array}$ & serpentine $\begin{array}{l}\text { antigonite } \\
\text { chrysotile }\end{array}$ \\
\hline Plagioclase & $\begin{array}{l}\text { sericite } \\
\text { chlorite }\end{array}$ \\
\hline \multicolumn{2}{|c|}{ Breccia matrix $=$ prehnite $^{\mathrm{a}}$, smectite, hematite } \\
\hline
\end{tabular}

12-1 do not occur embedded in glass rims of vesicle walls, but grow on a surface of smectite, attached in a single spot by a narrow stem. The origin of these pyrite framboids is problematic. However, it is interesting that most occurrences in sedimentary environments are interpreted as being of diagenetic origin associated with the activity of anaerobic sulphate-reducing bacteria (Love, 1964).

Amygdules occasionally contain basalt glass, which is at times partially devitrified and charged with plagioclase microlites. Palagonite, fibropalagonite, and saponite-nontronite occur as alterations of glass in amygdules.

5) Joint surfaces exhibit well-developed layers of phillipsite, saponite, saponite-nontronite, and less commonly calcite, hematite, and pyrite. Sample 332B-46-2, $24-26 \mathrm{~cm}$ displays a joint surface consisting of saponitenontronite and aggregates of pyrite crystals. It is interesting that all pyrite crystal faces are nonstriated (Plate 7).

6) Sample $332 \mathrm{~A}-9-1,38 \mathrm{~cm}$ is a breccia possibly derived from pillow basalt and consists of angular fragments of palagonite, fibropalagonite, fresh glass, and oxidized, partially devitrified glass. The matrix of finely crushed basaltic material is veined by phillipsite and minute quartz stringers. Phillipsite also occurs in vugs.

\section{Clay Minerals}

Clay minerals are the most abundant secondary phases occurring in basalts of Leg 37 . They display a wide range in occurrence, optical properties, and chemistry. X-ray data and chemical analyses indicate that these clay minerals all belong to the smectite group, occurring primarily as saponite, saponitenontronite mixed-layer clays, and more rarely nontronite. Dioctahedral and trioctahedral types were distinguished using mainly the 060 spacing (MacEwan, 1951, 1961; Berry, 1974). A number of specimens exhibit 060 spacing intermediate in value between nontronite and saponite, a feature which has also been observed by Melson and Thompson (1973). Such cases are interpreted as saponite-nontronite mixed-layer structures.

Clay minerals occur as (1) vesicles fillings, (2) vein fillings, (3) alteration products of olivine, (4) alteration products of palagonite, and (5) less commonly, as alteration products of plagioclase. In general, color ranges from shades of green, brown, and red to colorless and almost black. Color also appears to correlate well with chemistry. In this respect green and red varieties are relatively $\mathrm{Fe}$ rich and $\mathrm{Mg}$ poor, whereas colorless and black varieties are $\mathrm{Mg}$ rich and $\mathrm{Fe}$ poor. Clay minerals are either cryptocrystalline or very finely crystallized. Cryptocrystalline varieties occur mainly as vesicle fillings and commonly exhibit complex color zonations, going from green to brown to colorless and black, from rim to core (Plate 8). With crossed nicols, lamellar structures are common and interference colors are usually masked. Finely crystalline varieties display very small rosette clusters of crystals exhibiting firstorder birefringence and occur as vesicle fillings and alteration products of olivine and plagioclase.

Twenty-eight chemical analyses of smectite in nine zoned vesicles are listed in Appendix A. Averages of these analyses appear in Table 3 . These data reveal a number of interesting details with respect to chemistry and structure:

1) A comparison of the chemical analyses listed in Appendix I with those cited in the literature (Sudo, 1954; Miyamoto, 1957; Deer et al., 1962; Kohyama et al., 1973) indicates that the clay mineral in all vesicles analyzed is potassium-rich saponite. X-ray analysis of material separated from a vesicle in Sample 332B-37-2, $18-20 \mathrm{~cm}$ suggests that both rim and core are saponite.

2) Color zonation reflects systematic changes in saponite chemistry from rim to core (Figures 2 and 3). Green $\mathrm{Fe}$ rich- $\mathrm{Mg}$ poor saponite in vesicle rims gradually undergoes transition to black $\mathrm{Mg}$ rich-Fe poor saponite in cores. $\mathrm{Al}_{2} \mathrm{O}_{3}$ and $\mathrm{Na}_{2} \mathrm{O}$ increase at the expense of $\mathrm{SiO}_{2}$ and $\mathrm{K}_{2} \mathrm{O}$ from rim to core. Oxide totals

\begin{tabular}{l|cccc|c}
\hline & $\begin{array}{c}\text { Fresh } \\
\text { Rock }\end{array}$ & $\begin{array}{c}\text { Oxidation } \\
\text { Fresh Rock } \\
\text { Interface }\end{array}$ & $\begin{array}{c}\text { Outer } \\
\text { Oxidized } \\
\text { Zone }\end{array}$ & $\begin{array}{c}\text { Inner } \\
\text { Intensely } \\
\text { Oxidized } \\
\text { Zone }\end{array}$ & \multicolumn{1}{|c}{ Vein } \\
\hline & & $1.5 \mathrm{~mm}$ & $4.5 \mathrm{~mm}$ & $2 \mathrm{~mm}$ & $1 \mathrm{~mm}$ \\
\hline Vesicle & Calcite & Saponite & $\begin{array}{c}\text { Saponite } \\
\text { Hematite }\end{array}$ & $\begin{array}{l}\text { Hematite } \\
\pm \text { calcite }\end{array}$ & $\begin{array}{l}\text { Clastic carbonate } \\
\text { Altered wall rock } \\
\text { fragments }\end{array}$ \\
& & & \pm calcite & \pm saponite & $\begin{array}{l}\text { Foraminiferal tests } \\
\text { Native copper }\end{array}$ \\
\hline
\end{tabular}

Figure 1. Systematic mineralogical changes in vesicles of Sample 332B$37-2,18-20 \mathrm{~cm}$. 
TABLE 3

Clay Mineral Analyses, Volcanic Rocks, DSDP, Leg 37

\begin{tabular}{|c|c|c|c|c|c|c|c|c|c|c|}
\hline & \multicolumn{4}{|c|}{$332 \mathrm{~B}-37-2,18-20 \mathrm{~cm}$} & \multicolumn{4}{|c|}{$335-5-2,24-26 \mathrm{~cm}$} & \multicolumn{2}{|c|}{$\begin{array}{l}332 \mathrm{~B}-25-2 \\
112-114 \mathrm{~cm}\end{array}$} \\
\hline & $\begin{array}{c}\text { Rim } \\
\text { Green }\end{array}$ & Brown & Colorless & $\begin{array}{l}\text { Core } \\
\text { Black }\end{array}$ & $\begin{array}{l}\text { Rim } \\
\text { Red }\end{array}$ & Green & Brown & $\begin{array}{c}\text { Core } \\
\text { Colorless }\end{array}$ & $\begin{array}{l}\text { Rim } \\
\text { Red }\end{array}$ & $\begin{array}{l}\text { Core } \\
\text { Green }\end{array}$ \\
\hline $\mathrm{SiO}_{2}$ & 47.12 & 48.13 & 44.07 & 38.62 & 44.93 & 49.74 & 50.05 & 47.58 & 42.51 & 46.96 \\
\hline $\mathrm{Al}_{2} \mathrm{O}_{3}$ & 4.12 & 4.39 & 6.71 & 7.14 & 2.72 & 1.31 & 1.36 & 2.00 & 1.01 & 0.68 \\
\hline $\mathrm{FeO}$ & 25.26 & 16.30 & 7.31 & 5.63 & 24.67 & 29.03 & 24.26 & 8.96 & 34.96 & 28.55 \\
\hline $\mathrm{MgO}$ & 10.30 & 17.29 & 23.33 & 22.70 & 14.45 & 4.83 & 6.96 & 16.89 & 5.95 & 5.69 \\
\hline $\mathrm{CaO}$ & 0.86 & 1.07 & 1.05 & 0.59 & 0.47 & 0.28 & 0.28 & 0.22 & 0.29 & 0.15 \\
\hline $\mathrm{Na}_{2} \mathrm{O}$ & 0.15 & 0.42 & 0.46 & 0.51 & 1.03 & 0.33 & 0.28 & 0.30 & 0.40 & 0.38 \\
\hline $\mathrm{K}_{2} \mathrm{O}$ & 3.42 & 2.05 & 0.31 & 0.33 & 2.40 & 6.33 & 6.55 & 3.50 & 3.81 & 5.94 \\
\hline $\mathrm{TiO}_{2}$ & 0.02 & 0.01 & - & - & 0.04 & 0.01 & 0.01 & - & 0.01 & 0.02 \\
\hline $\mathrm{MnO}$ & 0.07 & - & 0.05 & 0.03 & 0.08 & 0.03 & 0.24 & 0.02 & 0.06 & 0.03 \\
\hline Total & 91.32 & 89.87 & 83.29 & 75.55 & 90.79 & 91.89 & 89.99 & 79.47 & 89.00 & 88.40 \\
\hline
\end{tabular}

Note: $\mathrm{FeO}$ represents total iron. These data are averages in wt \% derived from chemical analyses listed in Appendix I. Dash indicates not present. Values in wt \%.

decrease systematically in the same direction and possibly reflect increasing amounts of $\mathrm{H}_{2} \mathrm{O}$ in interlayer positions. It is noteworthy that analyses of individual zones are consistent for all vesicles studied; for example, green saponite always occurs on vesicle rims and is consistently the $\mathrm{Fe}$ rich- $\mathrm{Mg}$ poor variety.

3) In Sample 335-5-2, 24-26 cm some vesicles display a thin orange to red zone which rims green iron-rich saponite adjacent to the vesicle wall. As illustrated in Table 3 , this zone does not comply with the chemical trends observed in the other zones. It is suggested that these rims represent reaction between saponite and wall rock as a result of late-stage, possibly oxidizing fluids introduced along vesicle walls.

4) Saponite structural formulas are listed in Tables 4 and 5 and represent averaged data from Samples 332B$37-2,18-20 \mathrm{~cm}$ and $335-5-2,24-26 \mathrm{~cm}$, respectively. All formulas are calculated on the basis of 20 oxygens and four hydroxyls. $\mathrm{Si}+\mathrm{Al}$ totals of structural formulas in Table 4 are all essentially constant and sum to approximately eight, which corresponds well with that of the idealized structural formula. From rim to core, systematic substitution of $\mathrm{Mg}$ for $\mathrm{Fe}$ occurs in the octahedral site, however, the $\mathrm{Fe}+\mathrm{Mg}$ total increases in the same direction and, in the core, actually exceeds the total octahedral filling indicated by the idealized formula. This situation could be explained by the presence of small amounts of iron oxides intimately mixed with the core saponite and also causing the dark colors observed. Low oxide totals in core saponite probably indicate relatively large amounts of water in interlayer positions suggesting that water was increasingly available in the environment as core material crystallized. This situation would also be conducive to coprecipitation of iron oxides.

Formulas in Table 5 exhibit similar trends as those observed in Table 4, with the exception of the red rims, discussed above. Significantly higher $\mathrm{Al} / \mathrm{Si}$ ratios of saponite, represented in Table 5, necessitate the placing of $\mathrm{Al}$ in octahedral sites.

Zoned saponite vesicles exhibit consistent chemical gradients from rim to core suggesting that fluids pres- ent during their precipitation experienced a chemical evolution which involved gradual enrichment of $\mathrm{MgO}$, $\mathrm{Al}_{2} \mathrm{O}_{3}$, and possibly $\mathrm{Na}_{2} \mathrm{O}$, at the expense of $\mathrm{FeO}, \mathrm{SiO}_{2}$, and $\mathrm{K}_{2} \mathrm{O}$.

\section{Zeolites}

Phillipsite is second in overall abundance to clay minerals and with the exception of a few minor occurrences of analcite is the only zeolite occurring in the specimens studied. It occurs as space fillings in veins, vesicles and vugs, and is often closely associated with calcite and sometimes saponite. Both poorly formed grains and well-developed crystals growing in radiating clusters are common (Plate 9). Phillipsite is also observed as an alteration product of plagioclase and occurs as radiating fans (Plate 2), inclusion trains associated with cleavage traces, and irregular masses growing from fractures within the plagioclase grains. $\mathrm{X}$-ray confirmation of phillipsite as an alteration product of plagioclase has not been possible due to the incipient development, therefore identification is by optical methods alone. Analcite is only observed in very minor amounts and occurs in vesicles usually associated with palagonite (Plate 10). In their experimental studies on hydrothermal alteration, Hawkins and Roy (1963) note that andesite glass alters to the assemblage montmorillonite + phillipsite at temperatures below $250^{\circ} \mathrm{C}$. The assemblage montmorillonite + analcite appears only at higher temperatures.

\section{Palagonite}

Palagonite is a frequent constituent of basaltic breccia (Samples 332A-9-1, $38 \mathrm{~cm}$ and 335-6-5, 110-112 cm). In this environment it occurs as brown to green colloform masses, often containing unaltered phenocrysts of plagioclase, pyroxene, and olivine and sometimes displaying cores of fresh glass. Palagonite almost always displays alteration to fibropalagonite and close association with phillipsite and sometimes calcite. Fibropalagonite occurs along palagonite grain boundaries and adjacent to fractures within the palagonite grains. 


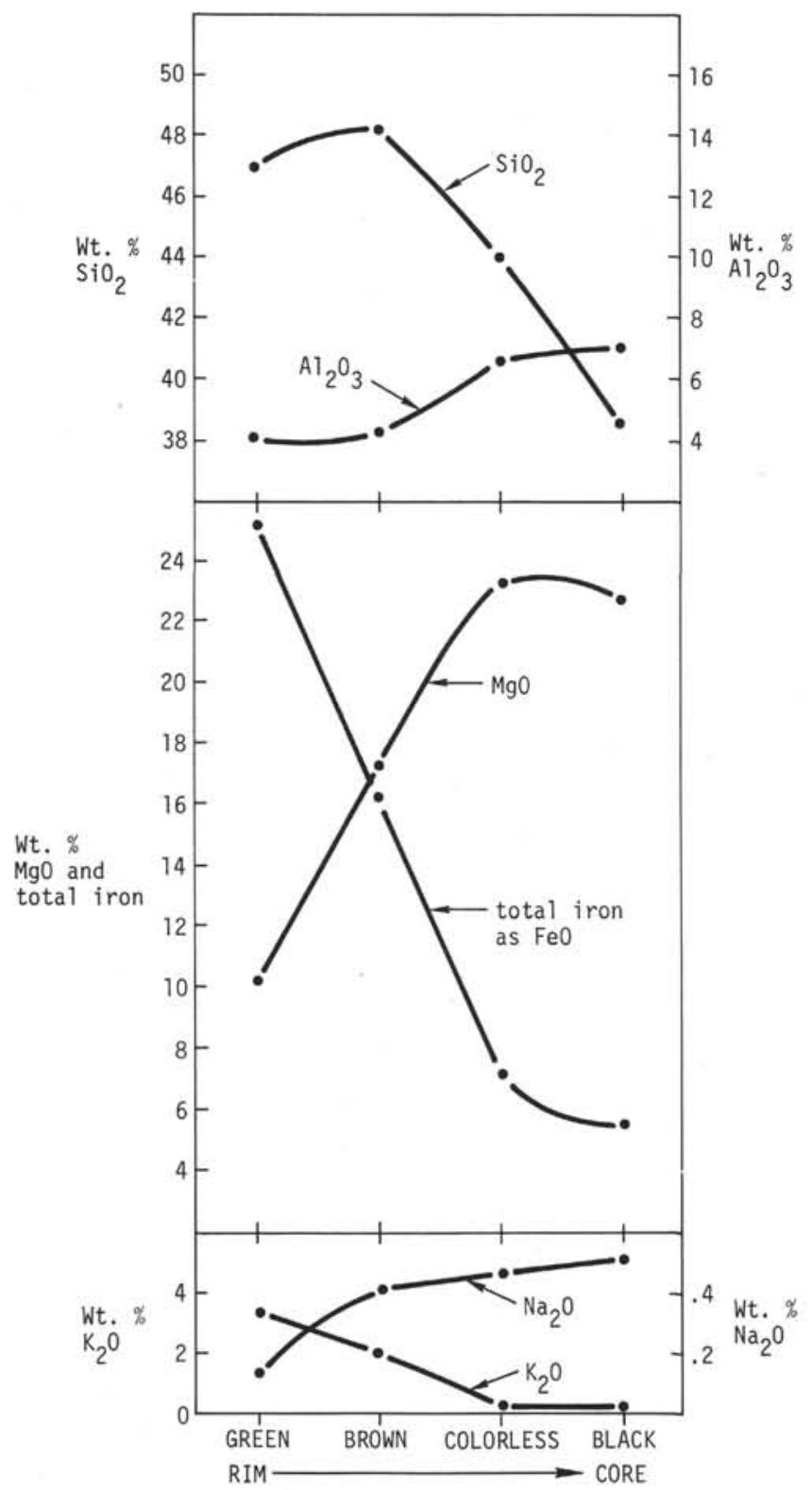

Figure 2. Chemical trends of zoned saponite occurring in vesicles of Sample 332B-37-2, $18-20 \mathrm{~cm}$. Plots are derived from averaged weight percent oxide analyses in Table 3.

$\mathrm{X}$-ray examination of fibropalagonite indicates that it consists mainly of saponite-nontronite. Phillipsite occurs in ovoid cavities and fractures within palagonite grains (Plate 11). In many cases it is possible to observe a progressive alteration of sideromelane to fibropalagonite and fibropalagonite to phillipsite. Botryoidal forms are observed developing from phillipsite vein walls within palagonite. Although this material is very inhomogeneous, electron microprobe analysis suggests that it probably consists of a mixture of clay minerals and iron-manganese hydroxides. As noted by Bonatti (1965), palagonite alteration probably occurs relatively soon after eruption during cooling of hydrated submarine lava.

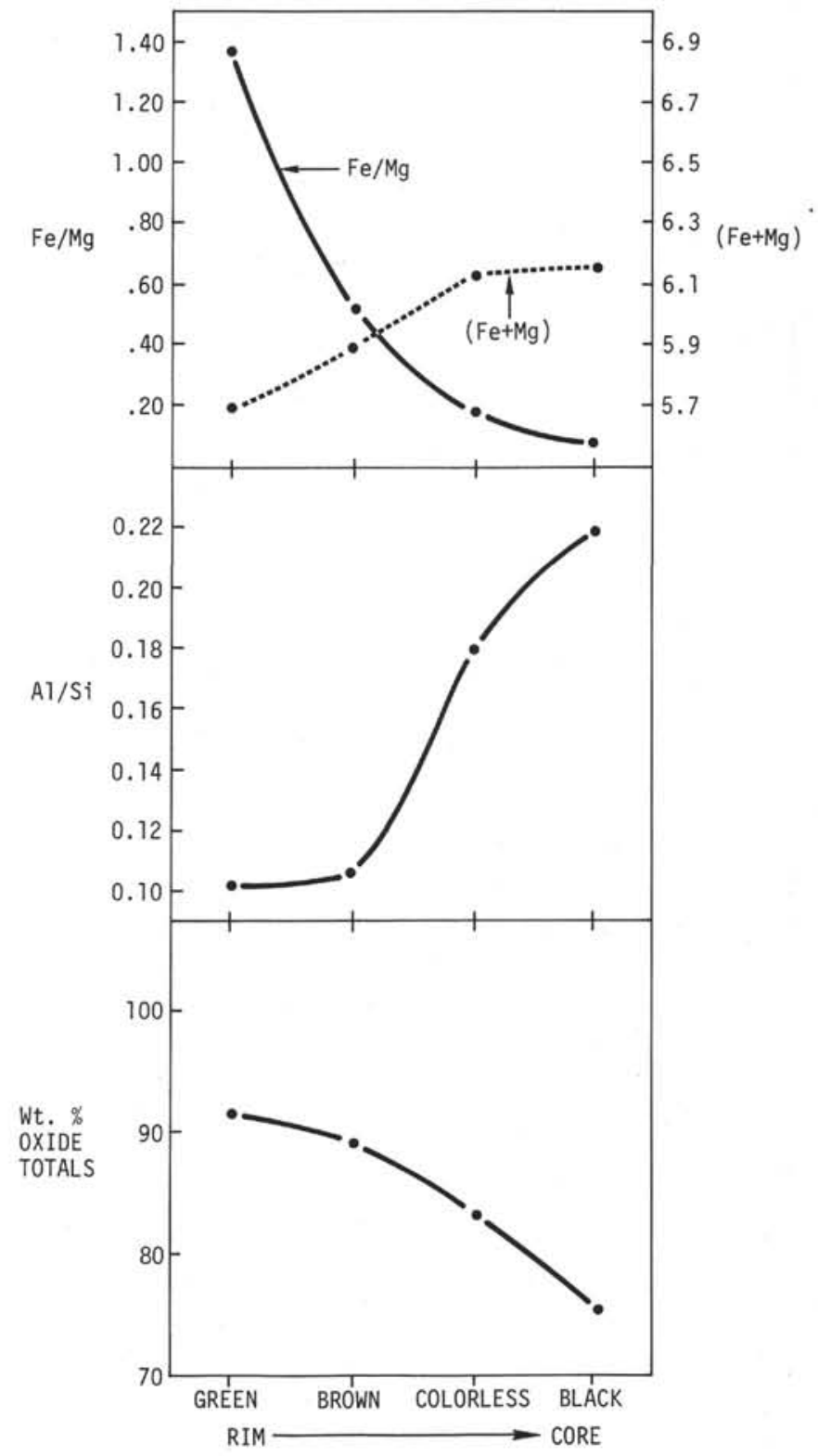

Figure 3. Chemical trends of zoned saponite occurring in vesicles of Sample 332B-37-2, 18-20 cm. Plots are derived from averaged weight percent oxide analyses in Table 3.

\section{Veins}

As previously discussed, evidence suggests that the main process of alteration affecting Leg 37 basalts has involved the introduction and movement of seawater through permeable areas. Veins and cracks are an important element of this permeability and exhibit a number of rather interesting features:

1) A survey of vein-filling types by X-ray analysis reveals that carbonate is the most abundant component consisting of mainly calcite and odd occurrences of aragonite and dolomite. Optical studies indicate that for the most part this carbonate is clastic rather than precipitated and often contains abundant foraminiferal 
TABLE 4

Structural Formulas of Saponites from Zoned Vesicles, Sample 332B-37-2, 18-20 cm

\begin{tabular}{|c|c|c|c|c|}
\hline & Zone & Tetrahedral Site & Octahedral Site & ge Cations \\
\hline \multirow[t]{3}{*}{ Rim } & G & $\left(\mathrm{Si}_{7.26} \mathrm{Al}_{0.75}\right)_{8.01}$ & $\left(\mathrm{Mg}_{2.40} \mathrm{Fe}_{3.30}\right)_{5.70}$ & $\left(\mathrm{Ca}_{0.14}{ }^{\mathrm{Na}} 0.04 \mathrm{~K}_{0.67}\right)$ \\
\hline & $\mathrm{Br}$ & $\left(\mathrm{Si}_{7.25} \mathrm{Al}_{0.77}\right)_{8.02}$ & $\left(\mathrm{Mg}_{3.86} \mathrm{Fe}_{2.04}\right)_{5.90}$ & $\left(\mathrm{Ca}_{0.17}{ }^{\mathrm{Na}} 0.13^{\mathrm{K}_{0.40}}\right)$ \\
\hline & & $\left(\mathrm{Si}_{6.79} \mathrm{Al}_{1.22}\right)_{8.01}$ & $\left(\mathrm{Mg}_{5.36} \mathrm{Fe}_{0.95}\right)_{6.31}$ & $\left(\mathrm{Ca}_{0.18}{ }^{\mathrm{Na}} 0.13 \mathrm{~K}_{0.06}\right)$ \\
\hline \multirow[t]{2}{*}{ Core } & Blac & $\left(\mathrm{Si}_{6.55} \mathrm{Al}_{1.43}\right)_{7.98}$ & $\left(\mathrm{Mg}_{5.74} \mathrm{Fe}_{0.80}\right)_{6.54}$ & $\left(\mathrm{Ca}_{0.11^{\mathrm{Na}}} 0.16^{\mathrm{K}_{0.08}}\right)$ \\
\hline & $\begin{array}{l}\text { Ideal } \\
\text { formu }\end{array}$ & $\left(\mathrm{Si}_{7.34} \mathrm{Al}_{0.66}\right)_{8.0}$ & & \\
\hline
\end{tabular}

Note: All formulas are calculated from averaged data in Table 3.

${ }^{\mathrm{a}}$ After Deer et al. (1962).

TABLE 5

Structural Formulas of Saponites from Zoned Vesicles, Sample 335-5-2, 24-26 cm

\begin{tabular}{|c|c|c|c|c|}
\hline & Zone & Tetrahedral Site & Octahedral Site & Exchange Cations \\
\hline \multirow[t]{3}{*}{ Rim } & Red rim & $\left(\mathrm{Si}_{7.0} \mathrm{Al}_{0.51} \mathrm{Fe}^{3+}{ }_{0.49}\right)_{8.0}$ & $\left(\mathrm{Mg}_{3.35} \mathrm{Fe}_{2.72}\right)_{6.07}$ & $\left(\mathrm{Ca}_{0.08}{ }^{\mathrm{Na}} 0.32^{\mathrm{K}_{0.47}}\right)$ \\
\hline & Green & $\left(\mathrm{Si}_{7.93} \mathrm{Al}_{0.07}\right)_{8.0}$ & $\left(\mathrm{Mg}_{1.15} \mathrm{Fe}_{3.87} \mathrm{Al}_{0.18}\right)_{5.20}$ & $\left(\mathrm{Ca}_{0.05}{ }^{\mathrm{Na}} 0.10^{\mathrm{K}_{1.28}}\right)$ \\
\hline & Brown & $\left(\mathrm{Si}_{7.98} \mathrm{Al}_{0.02}\right)_{8.0}$ & $\left(\mathrm{Mg}_{1.66} \mathrm{Fe}_{3.24} \mathrm{Al}_{0.23}\right)_{5.13}$ & $\left(\mathrm{Ca}_{0.04}{ }^{\mathrm{Na}} 0.10^{\mathrm{K}_{0.73}}\right)$ \\
\hline \multirow[t]{2}{*}{ Core } & White & $\left(\mathrm{Si}_{7.80} \mathrm{Al}_{0.20}\right)_{8.0}$ & $\left(\mathrm{Mg}_{4.13} \mathrm{Fe}_{1.23} \mathrm{Al}_{0.19}\right)_{5.55}$ & $\left(\mathrm{Ca}_{0.04}{ }^{\mathrm{Na}} 0.10^{\mathrm{K}_{0.73}}\right)$ \\
\hline & Ideal & $\left(\mathrm{Si}_{7.34} \mathrm{Al}_{0.66}\right)_{8.0}$ & $(\mathrm{Mg})_{6}$ & $(1 / 2 \mathrm{Ca}, \mathrm{Na})_{0.66}$ \\
\hline
\end{tabular}

Note: All formulas are calculated from average data in Table 3.

${ }^{\mathrm{a}}$ After Deer et al. (1962).

tests (Plate 12). This material has obviously originated from sediment off the ocean floor. In many cases veins display a centrally located "seam" reflecting the shape of the wall rock (Plate 12). Such features are also observed in quartz veins (Durney and Ramsey, 1973) and indicate the original fracture from which the vein developed. Its preservation here suggests that material was sluiced through by flowing seawater. Foraminiferal tests and seams are observed even in cracks of less than $1 \mathrm{~mm}$ width and reflect the penetrative power of circulating seawater.

2) Oxidation halos nearly always occur adjacent to cracks and veins indicating the volume of rock which has interacted with passing seawater (Plate 13). It is significant that oxidation halos are usually 10-15 times and up to 20 times the width of the fracture or vein. This is significant with respect to any estimate concerning potential volume of basalt-seawater interaction and possible leaching effects. Such estimates should not be made on fracture frequency alone.

3) Carbonate veins commonly contain abundant angular, opaque fragments which have been identified as highly altered wall rock (Plate 14). These fragments sometimes exhibit remnant cores of unaltered silicate material, but for the most part consist of hematite, possible manganese oxides, and finely disseminated magnetite, the latter most likely a residual phase from the original basaltic material. A vein occurring in Sample $332 \mathrm{~B}-37-2,18-20 \mathrm{~cm}$ is approximately $1 \mathrm{~mm}$ wide and consists of clastic carbonate, abundant, altered wall rock fragments, and occasional foraminiferal tests. This specimen is of particular interest since small blebs of native copper occur within the highly altered parts of many wall rock fragments. In the same specimen, native copper is also observed within a hematite amygdule, which is $3 \mathrm{~mm}$ from the vein and well within the associated oxidation halo. Any speculation about the origin of this native copper must consider at least two possibilities: (1) that it represents a residual phase of the original basalt, and (2) that it precipitated from seawater which was also responsible for the wall rock alteration. Native copper is not observed as a primary phase in any of the fresh basalts studied here; in fact, Section $332 \mathrm{~B}-27-2$ is the only occurrence observed so far. Electron microprobe analyses indicate that altered wall rock fragments in this specimen are commonly enriched in iron and manganese, suggesting the possible presence of iron and manganese hydroxides. Indeed the botryoidal-like shape of some of these fragments also suggests this. Krauskopf (1956) observed experimentally that metals may be adsorbed onto certain colloidal materials, such as hydrated $\mathrm{MnO}_{2}$, from undersaturated solutions. Whether or not such a process was significant in this case cannot be deduced at this time.

\section{TRACE ELEMENTS}

Spark source mass spectroscopy was used to study the possible effects of low-temperature seawater-basalt interaction on the distribution of $\mathrm{Mn}, \mathrm{Ti}, \mathrm{Ni}, \mathrm{Co}, \mathrm{Cu}$, $\mathrm{Zn}$, Sr. Thirteen analyses were conducted on four samples exhibiting veins and well-developed oxidation halos (Table 6). Each sample was separated with respect to fresh (unoxidized) rock, oxidized rock, intensely oxidized rock, and vein material.

The data in Table 6 indicate that, with the possible exception of $\mathrm{Mn}$, interaction with low-temperature seawater did not cause any systematic redistribution or mobilization of the elements studied. Rather 
anomalous values in some of the vein material is attributable to the presence of wall rock fragments as discussed above. Ellis (1968) in his experimental work on hot water-rock interaction subjected andesite to 2 and 4 $M$ solutions at $400^{\circ} \mathrm{C}$ and after several weeks observed the almost complete removal of copper. In these experiments alteration was minimal and amounted to surface corrosion of pyroxene and the appearance of a few percent quartz and montmorillonite. Although the DSDP basalts studied here were subjected to $\mathrm{NaCl}$ solutions (seawater) and also show alteration to minerals of the montmorillonite group, there is no evidence to suggest temperatures as high as $400^{\circ} \mathrm{C}$. It seems that temperature is one of the critical factors controlling the mobility of metals such as copper in this environment and geological time is not necessarily a compensating factor at lower temperatures.

\section{SUMMARY}

Our conclusions concerning the process of fluid alteration of DSDP Leg 37 basalts may be summarized as follows:

1) The main process of alteration which has affected Leg 37 basalts involved the movement of lowtemperature fluids, most likely seawater, through permeable areas such as vesicles, cracks, and breccias. As a consequence, alteration occurs primarily in areas immediately adjacent to these channelways.

2) In the specimens studied, there is no evidence to suggest an increase in metamorphic grade with depth. Alteration is uniform and never exceeds zeolite grade. Exceptions to this are two specimens from Site 334, intensely hydrated, partly mylonitized gabbro breccias, which most likely are the result of faulting and concentration of hydrothermal fluids. Secondary minerals include prehnite, actinolite-tremolite, chlorite, serpentine, and amphibole.

3) Low-temperature basalt-seawater interaction has resulted in oxidation and hydration, involving the generation of abundant smectite (mainly saponite), zeolites (mainly phillipsite), and hematite. Olivine is often completely pseudomorphed by one or a combination of smectite, calcite, hematite, and sometimes iddingsite. Plagioclase is generally resistant to alteration, but exhibits incipient alteration to phillipsite. No definitive examples of pyroxene alteration are observed.

4) Amygdules sometimes exhibit systematic mineralogical changes with distance from a vein and the associated oxidation halo. In this respect amygdules change from mainly hematite adjacent to the vein, through iron-magnesium-rich saponite at the oxidation front, to calcite in relatively fresh rock. This probably reflects an environment which became decreasingly oxidizing from the vein outwards.

5) Clay-filled amygdules studied in detail by electron microprobe and X-ray analysis all consist of potassiumrich saponite which often exhibits complex color zonation. Color zonations reflect systematic changes in saponite chemistry. From rim to core this involves a gradual substitution of $\mathrm{Mg}$ for $\mathrm{Fe}$ in the octahedral site, an increase in $\mathrm{Al}_{2} \mathrm{O}_{3}$ and $\mathrm{Na}_{2} \mathrm{O}$ at the expense of $\mathrm{SiO}_{2}$

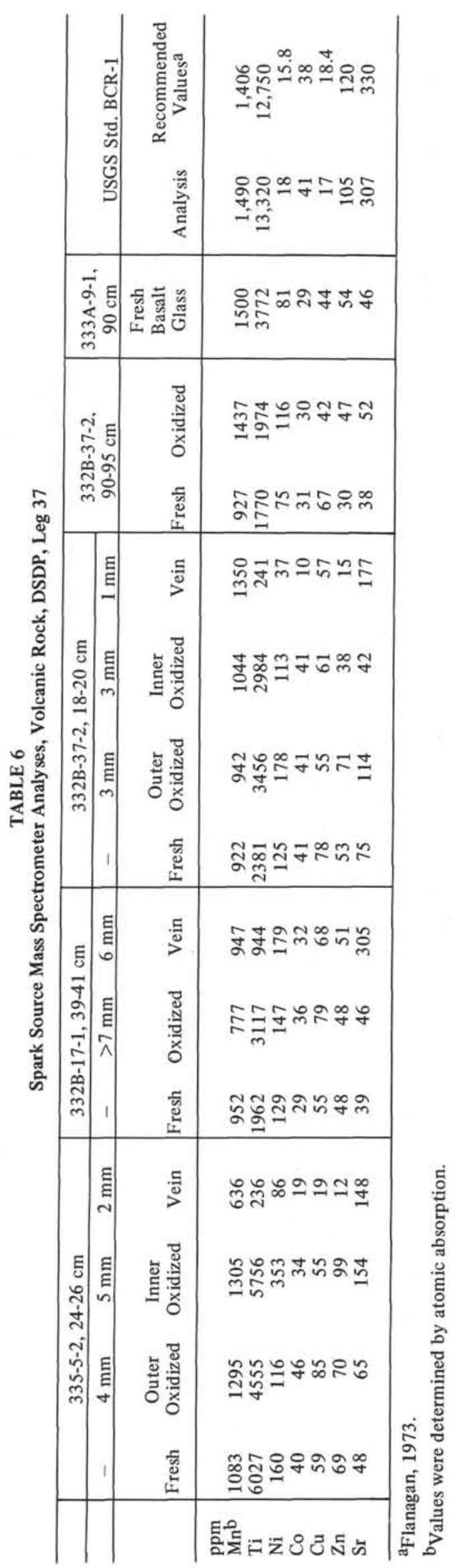


and $\mathrm{K}_{2} \mathrm{O}$, and a systematic decrease in oxide totals. The latter suggests increasing amounts of water in interlayer sites.

6) Oxidation halos are at least 10-15 times and sometimes 20 times the width of associated cracks or veins. This is significant with respect to any estimate concerning potential volume of basalt-seawater interaction and possible leaching effects. Such estimates should not be made on fracture frequency alone.

7) Veins in basalt typically consist of clastic carbonate, foraminiferal tests, and altered wall rock fragments. The former two represent ocean-floor material sluiced in by permeating seawater. In one specimen native copper occurs associated with altered wall rock fragments in the vein. Whether this native copper was indigenous to the original unaltered basalt or originated from the seawater responsible for the alteration is uncertain at this time.

8) Trace element data of fresh and oxidized basalt suggest that with the possible exception of $\mathrm{Mn}$, the distribution of $\mathrm{Ti}, \mathrm{Ni}, \mathrm{Co}, \mathrm{Cu}, \mathrm{Zn}$, and $\mathrm{Sr}$ is not affected by interaction with low-temperature, permeating seawater. In this environment the mobility of elements such as copper is probably not significant until much higher temperatures are reached and geological time does not appear to be a compensating factor at lower temperatures.

\section{REFERENCES}

Ahrens, L.H. and Taylor, S.R., 1961. Spectrochemical analysis (2nd ed.): Reading, Mass. (Addison-Wesley).

Berry, L.G. (Ed.), 1974. Selected powder diffraction data for minerals (1st ed.): Pennsylvania (Joint Committee on Powder Diffraction Standards).

Bonatti, E., 1965. Palagonite, hyaloclastites and alteration of volcanic glass in the ocean: Volcan. Bull., v. 28, p. 257.

Deer, W.A., Howie, R.A., and Zussman, J., 1962. Rockforming minerals, v. 3: London (Longman Group).

Durney, D.W. and Ramsey, J.G., 1973. Incremental strains measured by syntectonic crystal growths. In DeJong, K.A. and Scholten, R. (Eds), Gravity and tectonics: New York (Wiley-Interscience), p. 67.
Ellis, A.J., 1968. Natural hydrothermal systems and experimental hot-water/rock interaction: Reactions with $\mathrm{NaCl}$ solutions and trace element extraction: Geochim. Cosmochim. Acta, v. 32, p. 1356.

Flanagan, F.G., 1973. 1972 values for international geochemical reference samples: Geochim. Cosmochim. Acta, v. 37 , p. 1189.

Gandolfi, G., 1967. Discussion upon methods to obtain x-ray "powder patterns" from a single crystal: Mineral. Petrogr. Acta, v. 13, p. 67.

Hawkins, D.B. and Roy, R., 1963. Experimental hydrothermal studies on rock alteration and clay mineral formation: Geochim. Cosmochim. Acta, v. 27, p. 1047.

Kohyama, N., Shimoda, S., and Sudo, T., 1973. Iron-rich saponite (ferrous and ferric forms): Clays Clay Minerals, v. 21 , p. 229 .

Krauskopf, K.B., 1956. Factors controlling the concentrations of thirteen rare metals in sea water: Geochim. Cosmochim. Acta, v. 9, p. 1.

Love, L.G., 1964. Early diagenetic pyrite in fine-grained sediments and the genesis of sulphide ores. In G.C. Amstutz (Ed.), Sedimentology and ore genesis, v. 2: Amsterdam (Elsevier), p. 11.

MacEwan, D.M.C., 1951. The montmorillonite minerals (montmorillonoids). In Brindley, G.W. (Ed.), X-ray identification and crystal structure of clay minerals: London (Mineralogical Society, Clay Minerals Group), p. 86. 1961. Montmorillonite minerals. In Brown, G. (Ed.), The X-ray identification and crystal structure of clay minerals: London (Mineralogical Society, Clay Minerals Group), p. 143.

Melson, W.G. and Thompson, G., 1973. Glassy abyssal basalts, Atlantic sea floor near St. Paul's Rocks: Petrography and composition of secondary clay minerals: Geol. Soc. Am. Bull., v. 84, p. 703.

Miyamoto, N., 1957. Iron-rich saponite from Mazé Niigata Prefecture, Japan: Min. Journal (Japan), v. 2, p. 193.

Moore, J.G. and Galk, L., 1971. Sulphide spherules in vesicles of dredged pillow basalt: Am. Mineralogist, v. 56, p. 476.

Owens, E.B., 1966. Photographic emulsions as ion detectors in quantitative mass spectrography. In A hearn, A.J. (Ed.), Mass spectrometric analysis of solids: Amsterdam (Elsevier), p. 56.

Sudo, T., 1954. Iron-rich saponite found from tertiary iron sand beds of Japan: J. Geol. Soc. Japan, v. 60, p. 18. 
APPENDIX A

Clay Mineral Analyses, Samples 332B-37-2, 18-20; 335-5-2, 24-26 cm; and 332B-25-2, 112-114 cm

\begin{tabular}{|c|c|c|c|c|c|c|c|c|c|c|c|c|c|c|}
\hline \multirow{2}{*}{\begin{tabular}{|c|} 
Vesicle \\
Zone
\end{tabular}} & \multicolumn{4}{|c|}{1} & \multicolumn{4}{|c|}{2} & \multicolumn{3}{|c|}{3} & \multirow{2}{*}{$\frac{4}{\text { Green }}$} & \multicolumn{2}{|c|}{5} \\
\hline & Green & Brown & Colorless & Balck & Green & Brown & Colorless & Black & Green & Brown & Black & & Red & Green \\
\hline $\mathrm{SiO}_{2}$ & 48.40 & 47.09 & 43.72 & 39.40 & 46.79 & 49.49 & 44.41 & 37.86 & 47.53 & 48.45 & 38.59 & 45.77 & 43.17 & 49.99 \\
\hline $\mathrm{Al}_{2} \mathrm{O}_{3}$ & 4.01 & 4.72 & 6.98 & 4.93 & 4.59 & 4.47 & 6.44 & 8.03 & 3.86 & 3.97 & 8.46 & 4.03 & 3.01 & 0.97 \\
\hline $\mathrm{FeO}$ & 24.53 & 15.86 & 7.16 & 3.82 & 24.26 & 11.23 & 7.46 & 5.45 & 23.91 & 21.80 & 7.62 & 28.34 & 27.54 & 30.76 \\
\hline $\mathrm{MgO}$ & 10.43 & 19.45 & 23.55 & 20.56 & 11.29 & 21.04 & 23.11 & 22.36 & 10.28 & 11.38 & 25.16 & 9.19 & 12.92 & 5.53 \\
\hline $\mathrm{CaO}$ & 0.84 & 1.22 & 0.82 & 0.68 & 0.96 & 1.10 & 1.27 & 0.63 & 0.80 & 0.89 & 0.47 & 0.84 & 0.38 & 0.38 \\
\hline $\mathrm{Na}_{2} \mathrm{O}$ & - & 0.46 & 0.45 & 0.68 & 0.20 & 0.31 & 0.46 & 0.43 & 0.39 & 0.48 & 0.42 & - & 0.93 & 0.35 \\
\hline $\mathrm{K}_{2} \mathrm{O}$ & 3.68 & 0.76 & 0.29 & 0.53 & 3.21 & 1.50 & 0.32 & 0.27 & 3.83 & 3.90 & 0.20 & 2.95 & 2.69 & 4.65 \\
\hline $\mathrm{TiO}_{2}$ & 0.02 & - & - & - & 0.01 & - & - & - & 0.03 & 0.04 & - & - & 0.04 & - \\
\hline $\mathrm{MnO}$ & 0.05 & 0.01 & 0.08 & - & 0.08 & - & 0.01 & 0.01 & 0.02 & - & 0.05 & 0.11 & 0.08 & 0.04 \\
\hline Total & 91.96 & 89.57 & 83.06 & 70.60 & 91.40 & 89.14 & 83.48 & 75.04 & 90.64 & 90.91 & 80.96 & 91.25 & 90.78 & 92.68 \\
\hline H.I. & 1 & 1 & 1 & 1 & 0 & 1 & 2 & 1 & 1 & 1 & 1 & 1 & 1 & 1 \\
\hline
\end{tabular}

APPENDIX A - Continued

\begin{tabular}{|c|c|c|c|c|c|c|c|c|c|c|c|c|c|c|}
\hline \multirow{2}{*}{$\frac{\text { Vesicle }}{\text { Zone }}$} & \multicolumn{3}{|c|}{6} & \multicolumn{5}{|c|}{7} & \multicolumn{4}{|c|}{8} & \multicolumn{2}{|c|}{9} \\
\hline & Red & Green 1 & Green 2 & Green 1 & Green 2 & Brown & Brown & Colorless & Green 1 & Green 2 & Brown & Colorless & Red & Green \\
\hline $\mathrm{SiO}_{2}$ & 46.68 & 53.29 & 53.75 & 48.37 & 47.30 & 50.36 & 51.27 & 49.73 & 48.28 & 47.17 & 48.51 & 45.42 & 42.51 & 46.96 \\
\hline $\mathrm{Al}_{2} \mathrm{O}_{3}$ & 2.43 & 0.28 & 0.18 & 2.35 & 1.50 & 1.32 & 1.32 & 1.90 & 2.13 & 1.75 & 1.45 & 2.09 & 1.01 & 0.68 \\
\hline $\mathrm{FeO}$ & 21.79 & 26.69 & 27.26 & 31.74 & 29.10 & 25.85 & 21.87 & 12.13 & 29.81 & 27.88 & 25.05 & 5.78 & 34.96 & 28.55 \\
\hline $\mathrm{MgO}$ & 15.97 & 6.11 & 5.85 & 3.86 & 4.03 & 6.26 & 8.72 & 15.52 & 4.08 & 4.33 & 5.91 & 18.26 & 5.95 & 5.69 \\
\hline $\mathrm{CaO}$ & 0.56 & 0.15 & 0.11 & 0.39 & 0.32 & 0.27 & 0.27 & 0.25 & 0.34 & 0.28 & 0.29 & 0.18 & 0.29 & 0.15 \\
\hline $\mathrm{Na}_{2} \mathrm{O}$ & 1.12 & 0.34 & 0.25 & 0.29 & 0.28 & 0.26 & 0.25 & 0.30 & 0.39 & 0.38 & 0.32 & 0.29 & 0.40 & 0.38 \\
\hline $\mathrm{K}_{2} \mathrm{O}$ & 2.10 & 7.07 & 7.33 & 6.08 & 6.43 & 6.64 & 6.68 & 3.77 & 6.29 & 6.49 & 6.34 & 3.22 & 3.81 & 5.94 \\
\hline $\mathrm{TiO}_{2}$ & 0.03 & - & - & 0.04 & - & 0.02 & 0.02 & - & 0.04 & - & - & - & 0.01 & 0.02 \\
\hline $\mathrm{MnO}$ & 0.07 & 0.02 & 0.07 & - & 0.02 & 0.35 & 0.35 & - & 0.04 & 0.01 & 0.02 & 0.04 & 0.06 & 0.03 \\
\hline Total & 90.75 & 93.97 & 94.80 & 93.11 & 89.00 & 91.33 & 90.76 & 83.61 & 91.40 & 88.25 & 87.89 & 75.28 & 89.00 & 88.40 \\
\hline H.I & 1 & 1 & 1 & 1 & 0 & 1 & 1 & 1 & 1 & 1 & 1 & 1 & 2 & 1 \\
\hline
\end{tabular}

Note: $\mathrm{FeO}$ represents total iron. Dash indicates not present. H.I. is homogeneity index of $\mathrm{Si}$, calculated by dividing the variance of the set of counts by the mean number of counts in a single reading. A 10-sec count time is assumed. Green 1 - Green saponite adjacent to vesicle rim. Green 2 - Green saponite slightly more to the interior. Values in wt \%. 
PLATE 1

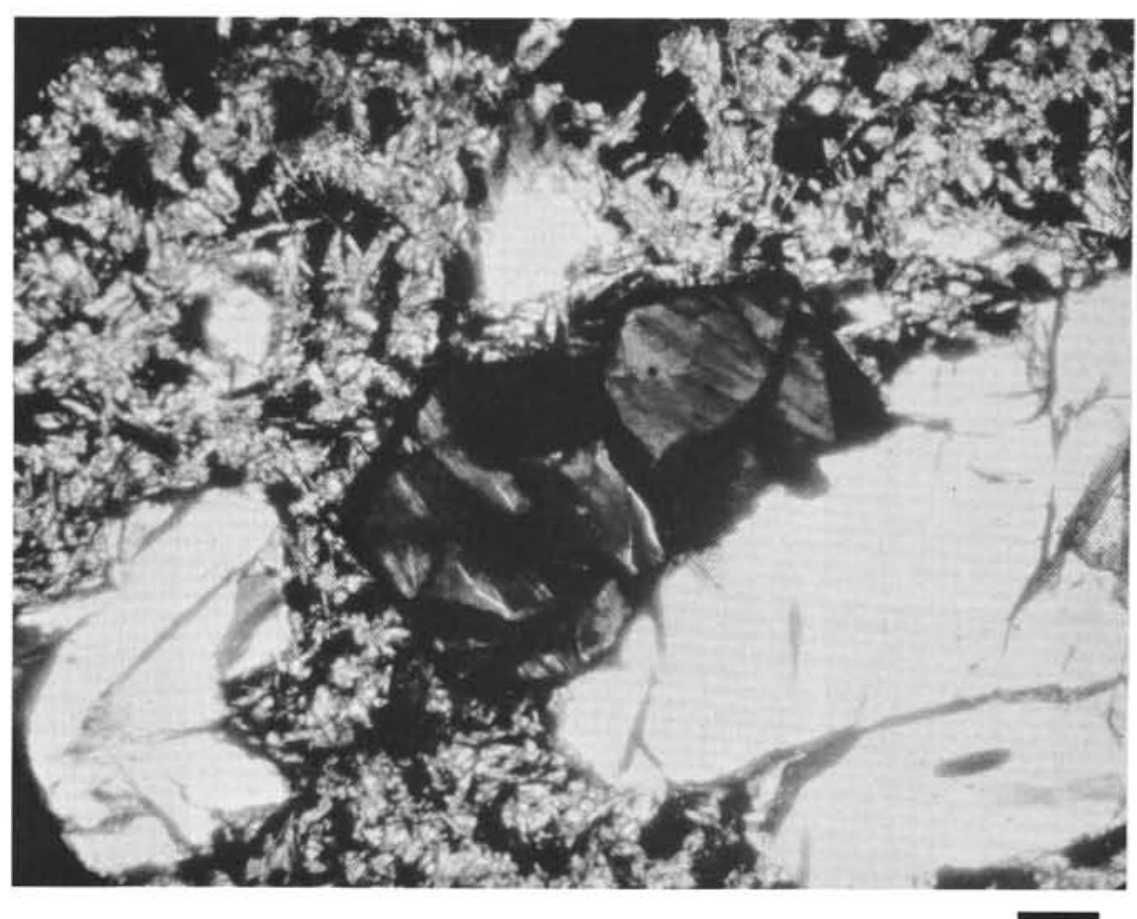

Sample 332B-37-2, $18-20 \mathrm{~cm}$. Pseudomorphed olivine phenocrysts replaced by fine-grained smectite in centers and hematite on rims. Plain light; scale bar $=0.5 \mathrm{~mm}$.

\section{PLATE 2}

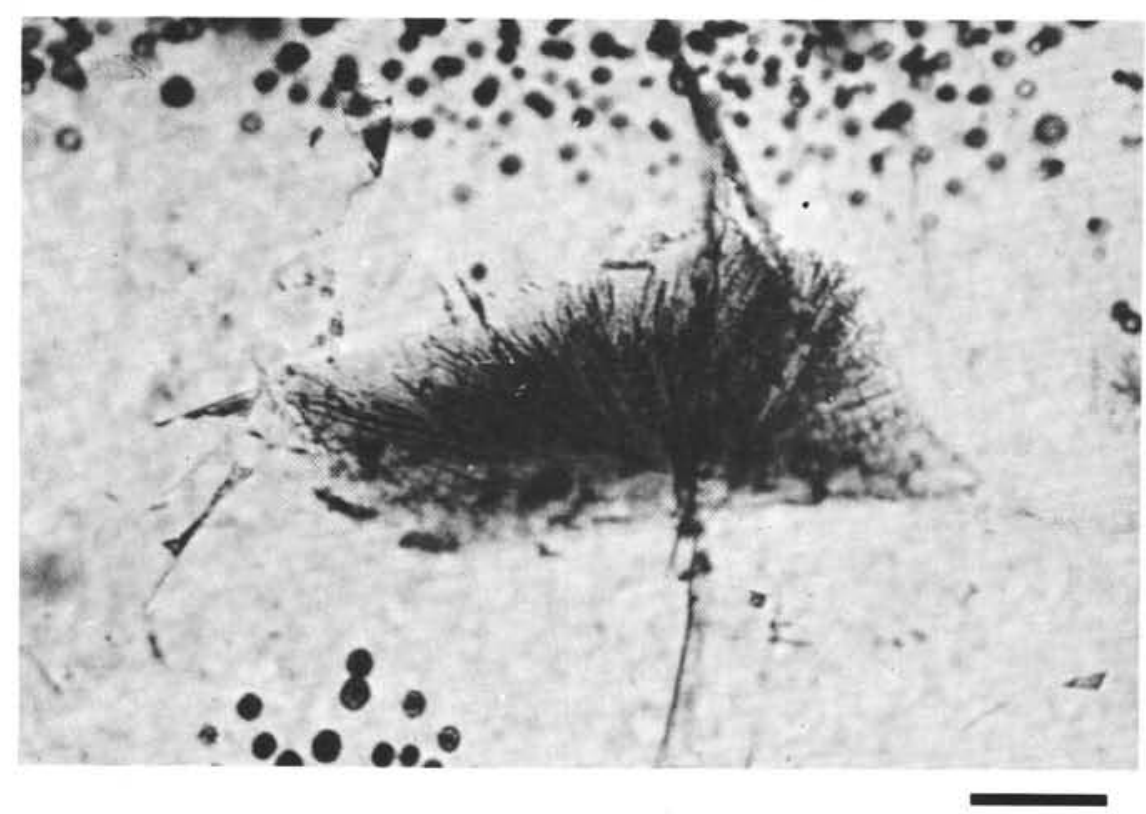

Sample 332B-37-2, 18-20 cm. Fan-shaped aggregate of phillipsite growing within a plagioclase phenocryst. Plain light; scale bar $=0.1 \mathrm{~mm}$. 
PLATE 3

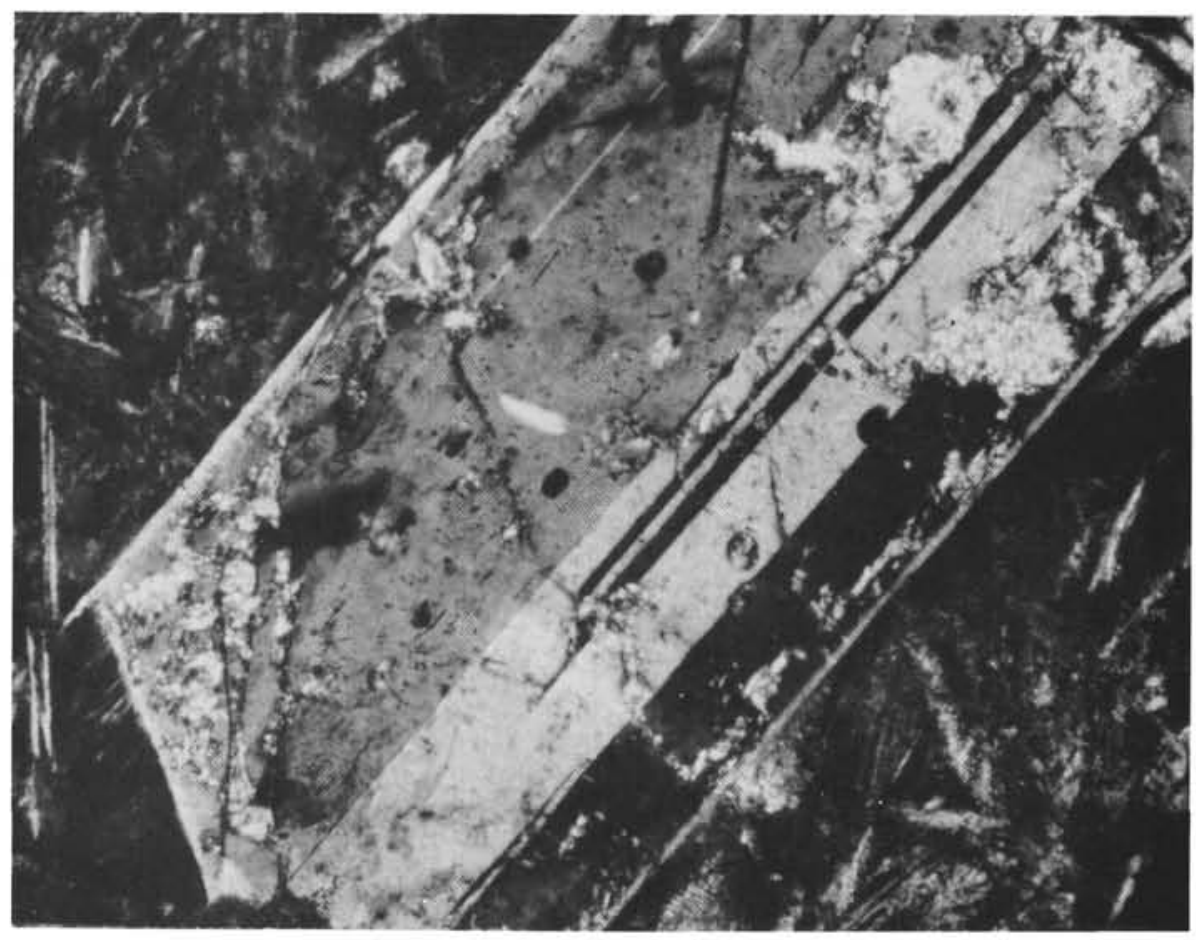

Sample 332B-36-3, 4-5 cm. Plagioclase phenocryst exhibiting alteration to smectite. Crossed polarizers; scale bar $=0.1 \mathrm{~mm}$.

\section{PLATE 4}

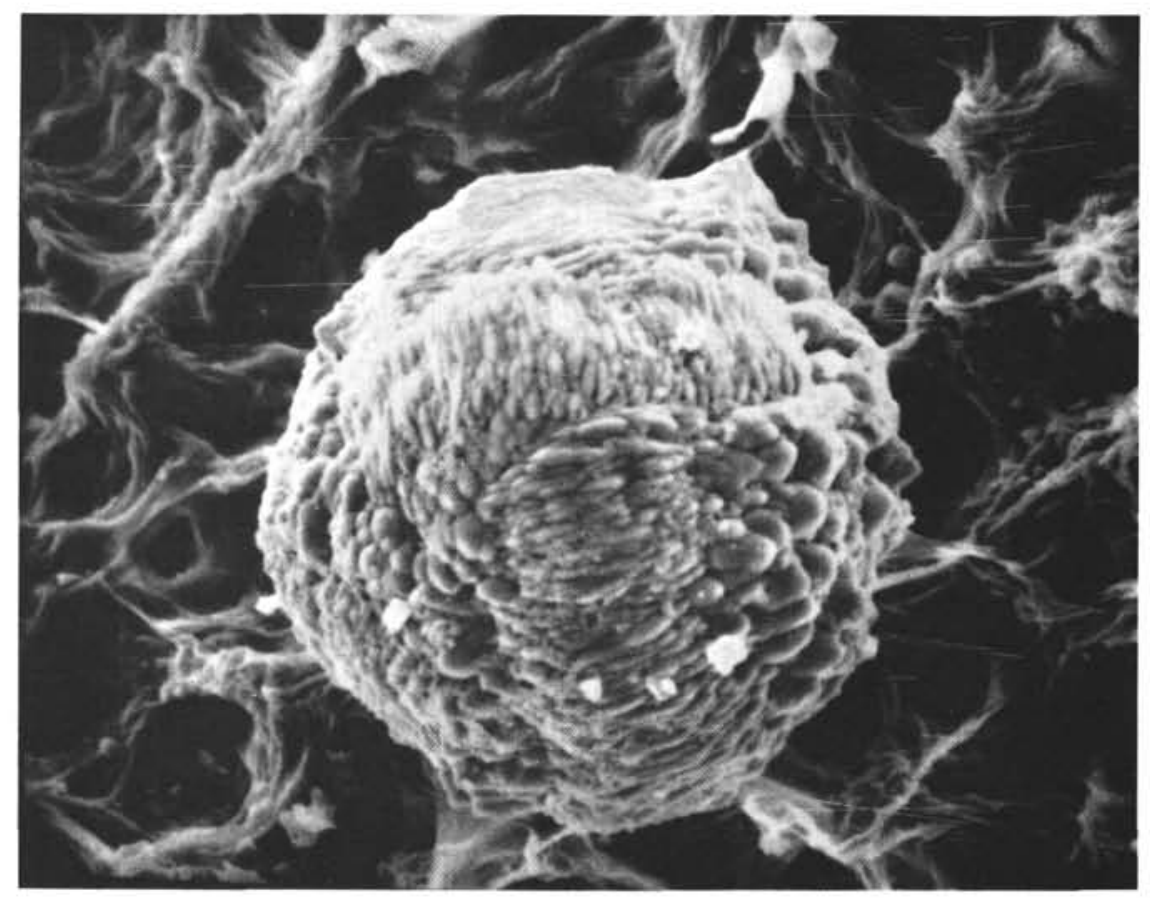

Sample 332A-12-1, 93-96 cm. Scanning electron micrograph of pyrite framboid growing from saponite-nontronite vesicle lining; 1480×. 
PLATE 5

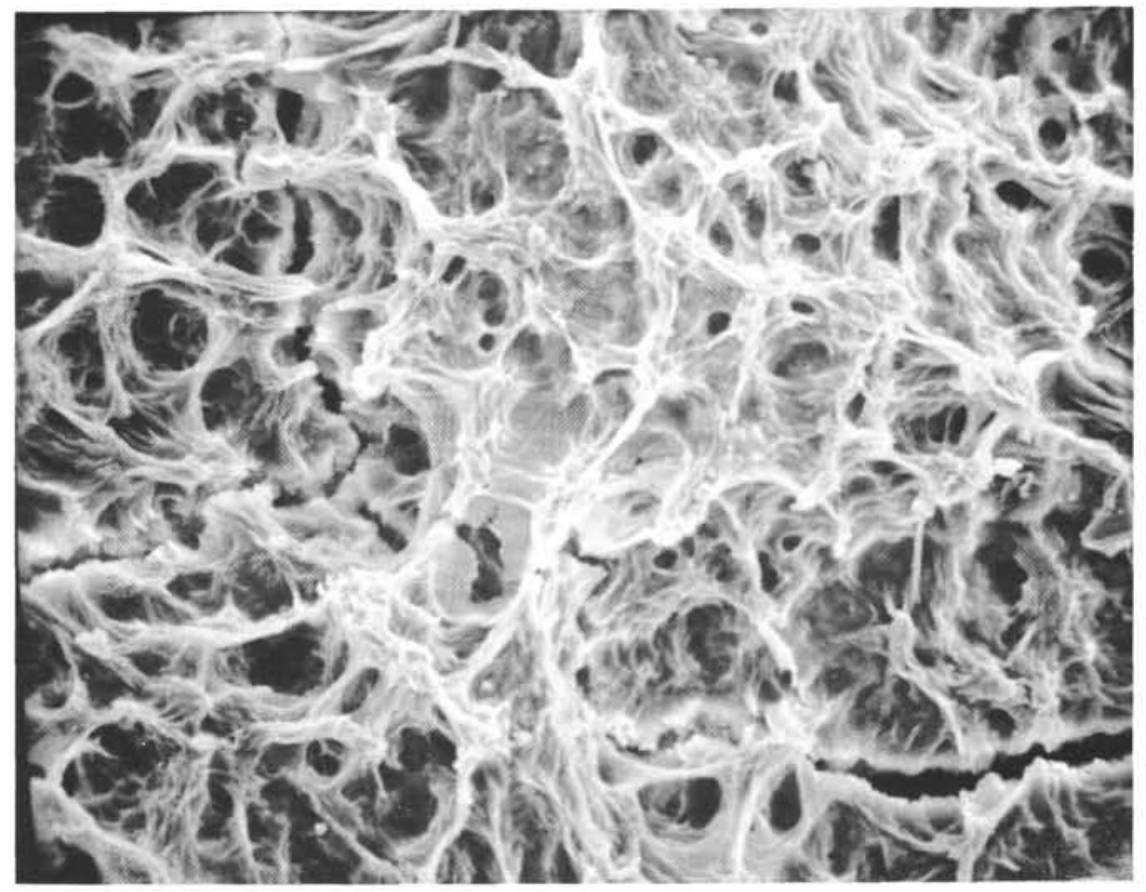

Sample 332A-12-1, 93-96 cm. Scanning electron micrograph of saponitenontronite web-like development of vesicle wall. $740 \times$.

PLATE 6

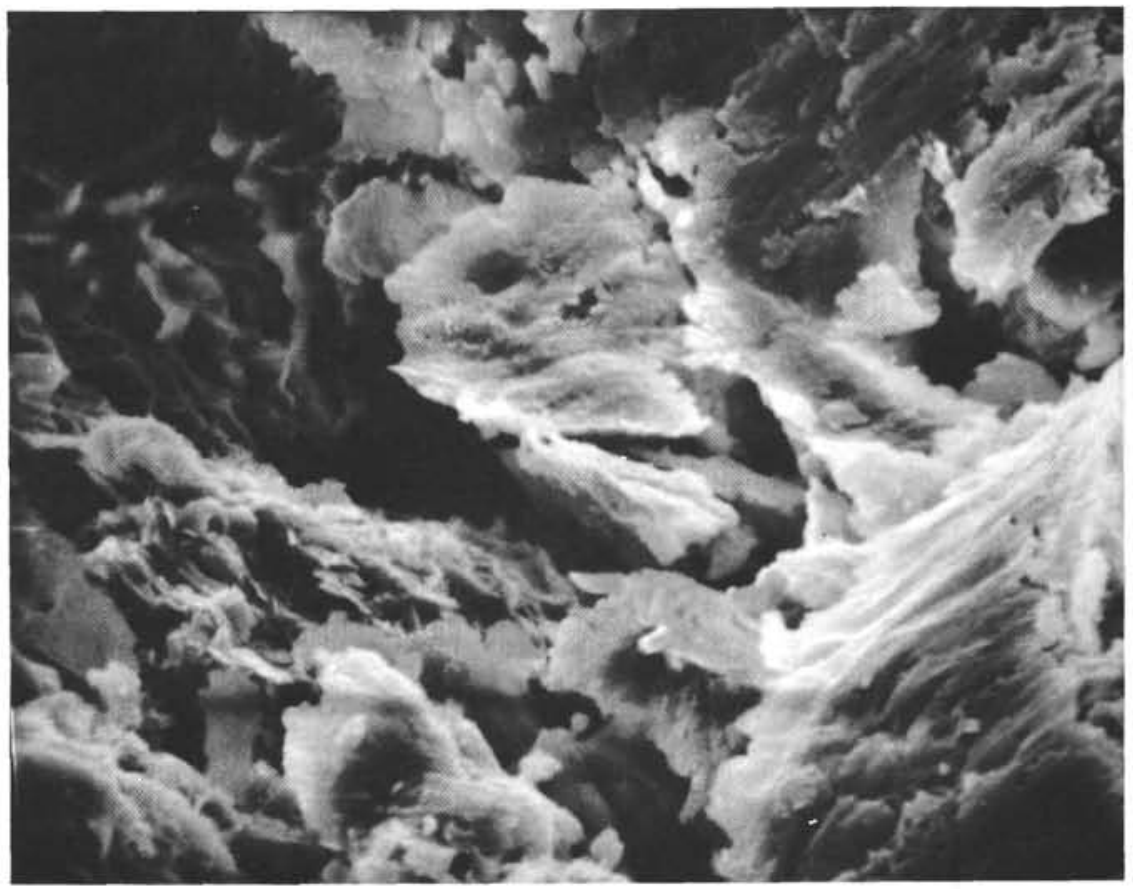

Sample 332A-12-1, 93-96 cm. Scanning electron micrograph of saponitenontronite particles. Close-up of Plate 5. 2220X. 
PLATE 7

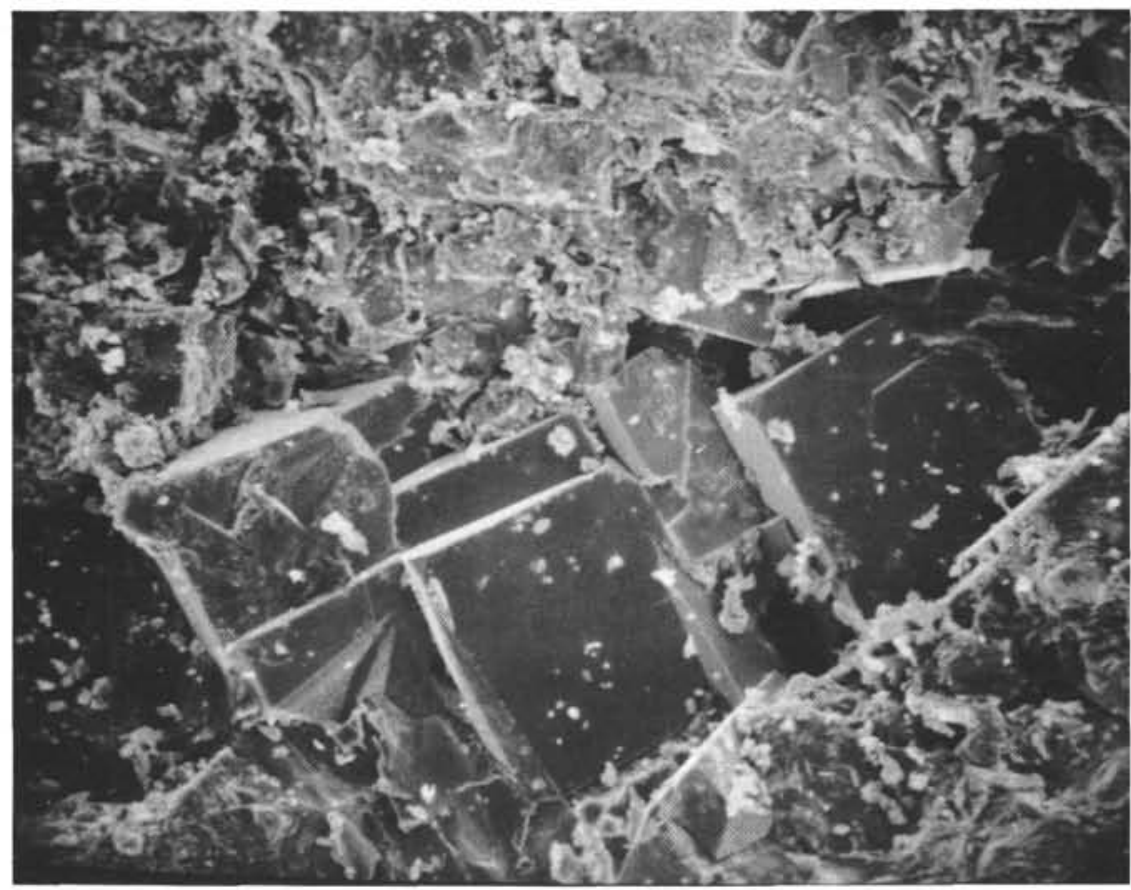

Sample 332B-46-2, 24-26 cm. Scanning electron micrograph of pyrite cubes and flakes of saponite-nontronite. Pyrite cube faces are nonstriated. $518 \times$.

\section{PLATE 8}

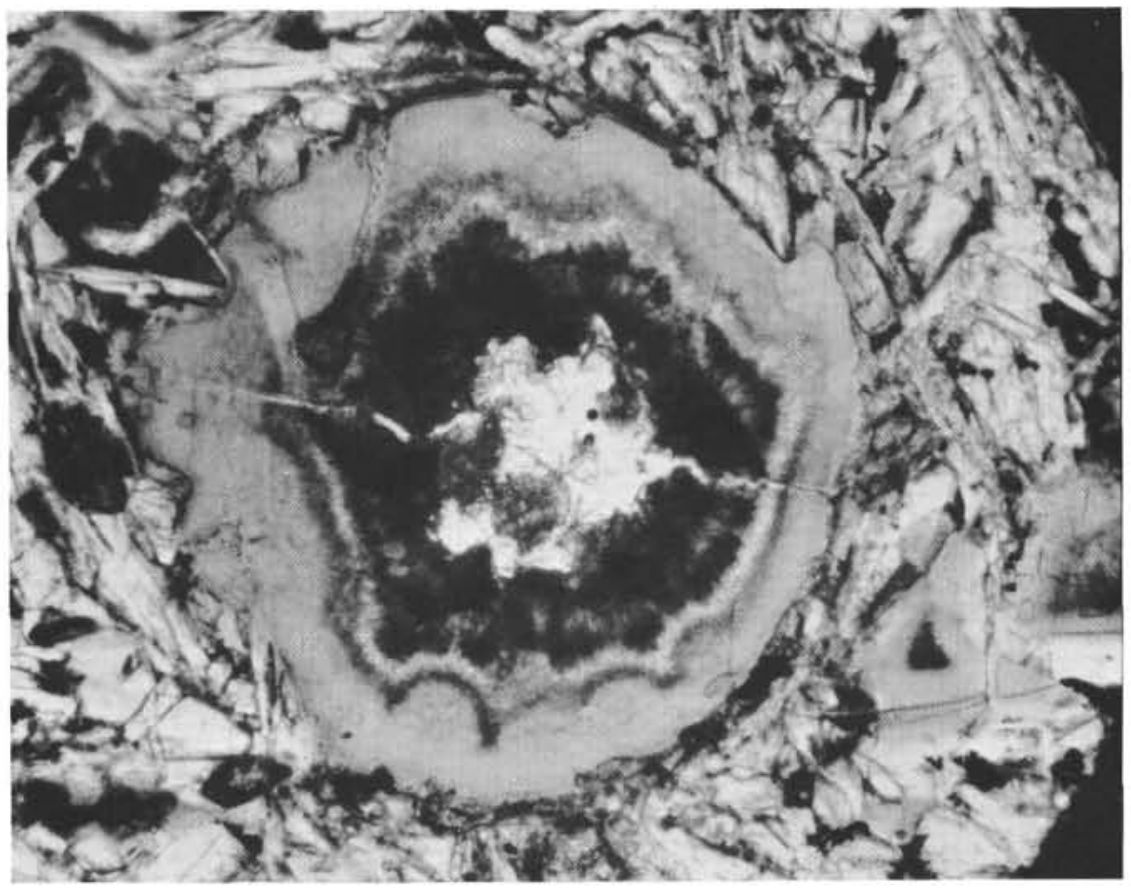

Sample 332B-46-2, 24-26 cm. Scanning electron micrograph of pyrite cubes and flakes of saponite-nontronite. Pyrite cube faces are nonstriated. $518 \times$. 


\section{PLATE 9}

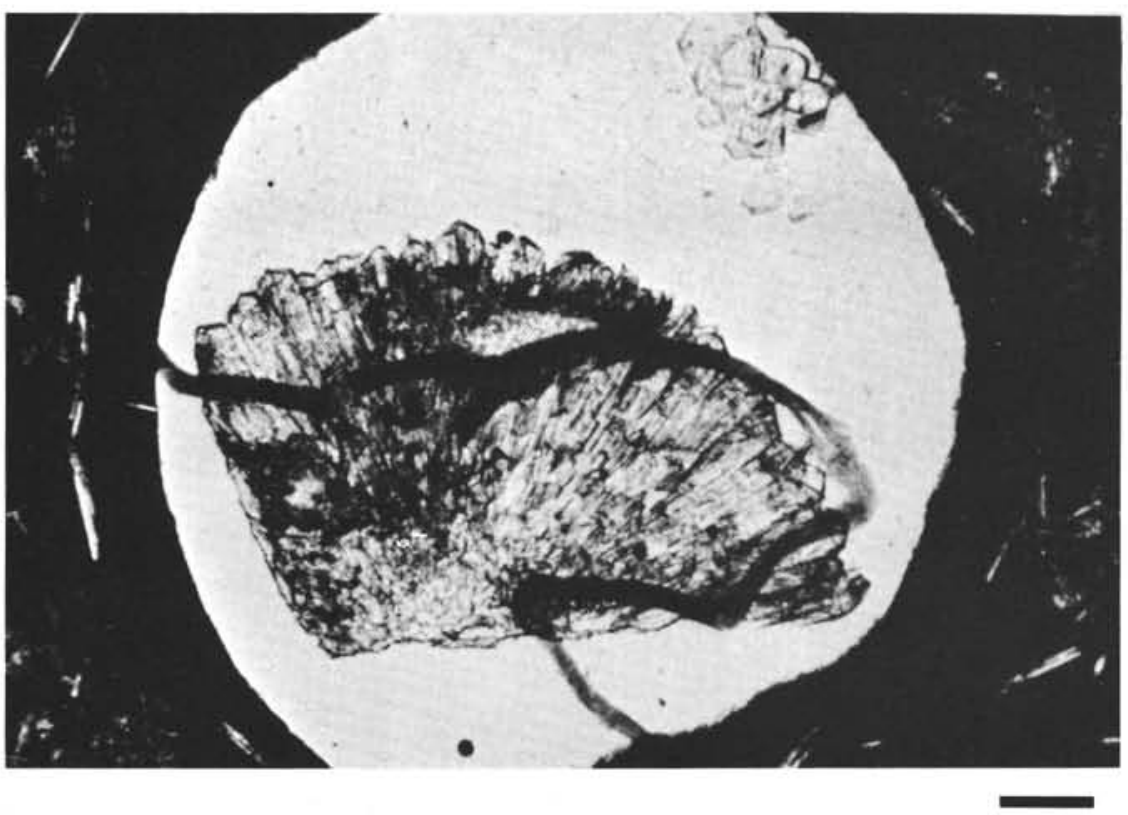

Sample 332A-9-1, $38 \mathrm{~cm}$. Vesicle containing a radiating cluster of phillipsite crystals. Plain light; scale bar $=0.1 \mathrm{~mm}$.

PLATE 10

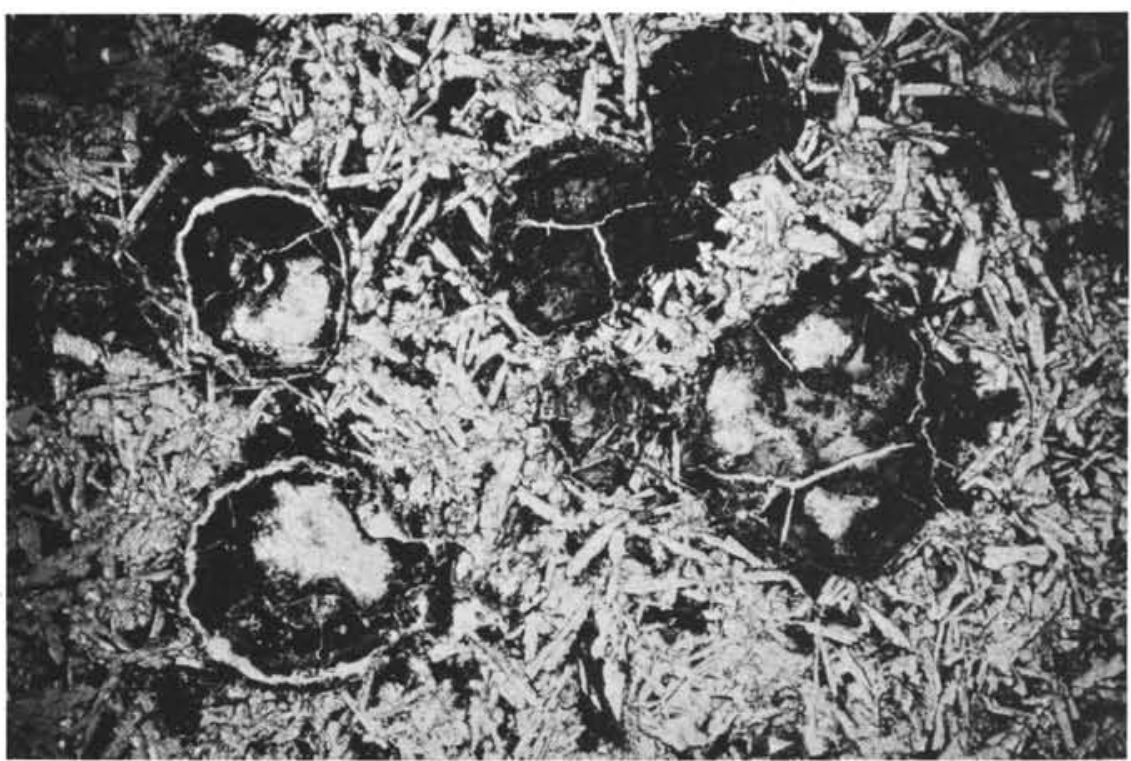

Sample 332B-46-1, 75-77 cm. Vesicles containing palagonite (dark) and analcite (colorless). Plain light; scale bar $=0.5 \mathrm{~mm}$. 


\section{PLATE 11}

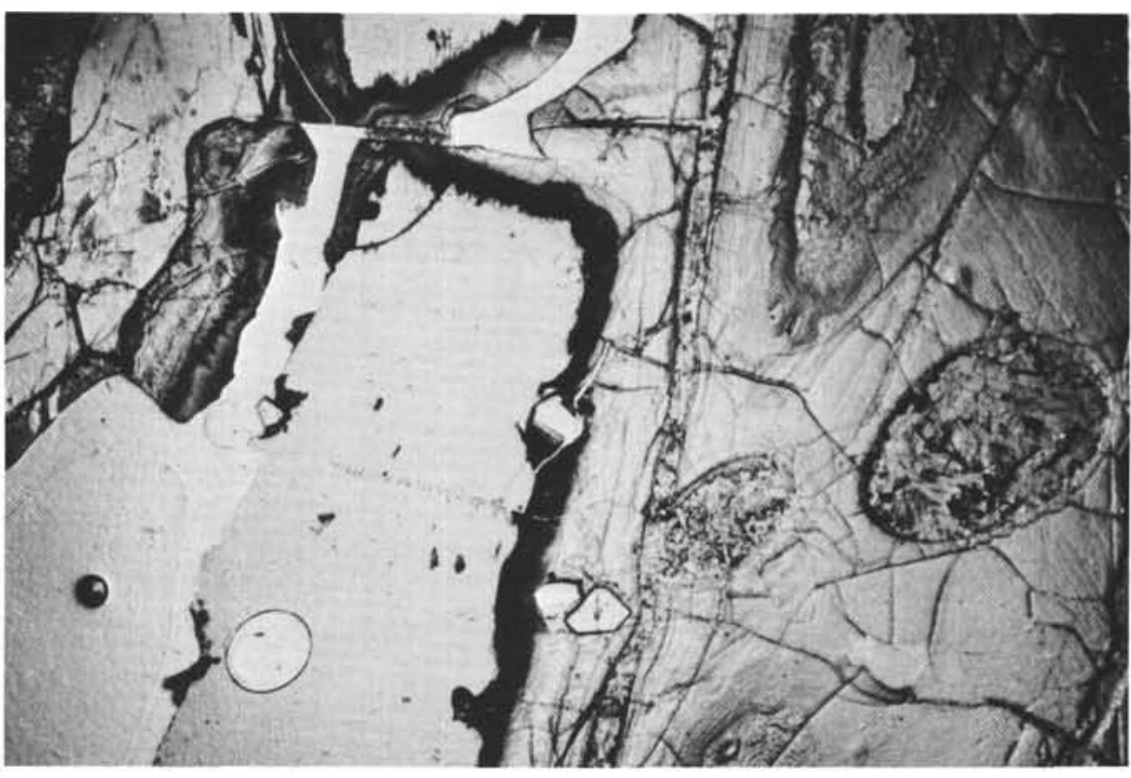

Sample 335-6-5, 110-112 cm. Breccia containing fragments of fresh glass altered to palagonite. Note unaltered olivine phenocrysts within palagonite and phillipsite in vein and filing ovoid cavity in palagonite. Plain light; scale bar $=0.5 \mathrm{~mm}$.

PLATE 12

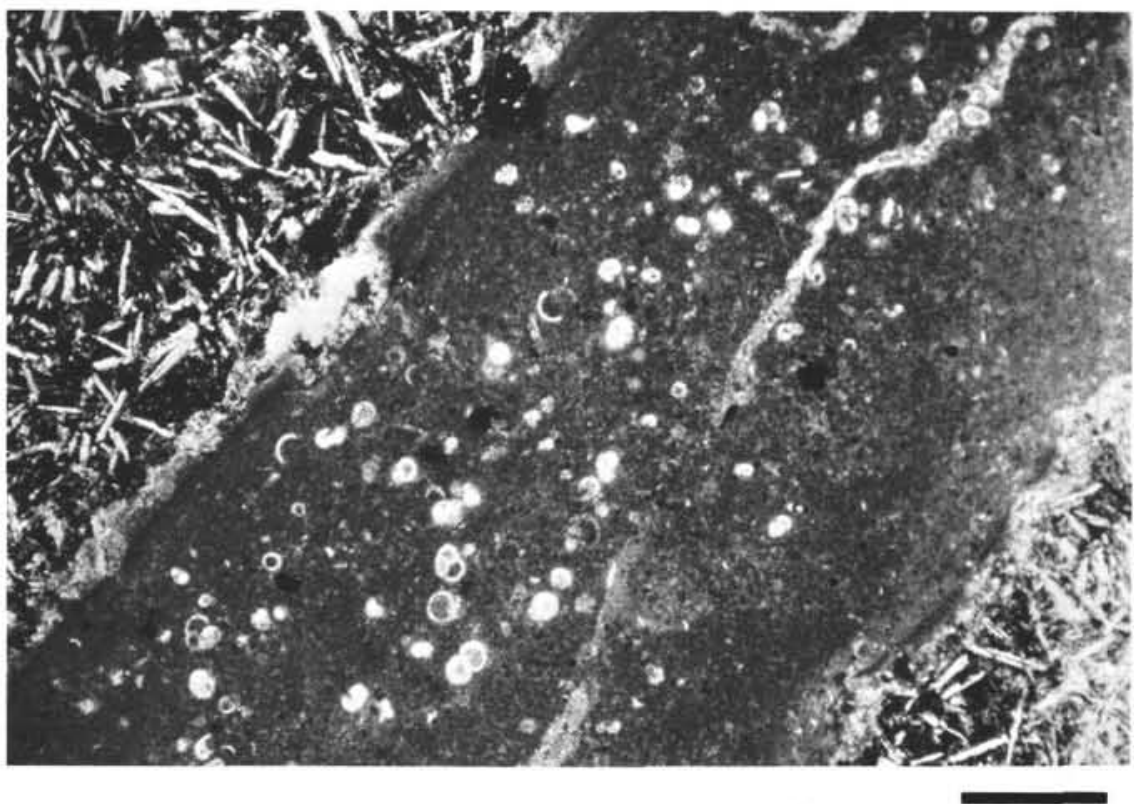

Sample 335-5-2, 24-26 cm. Vein in basalt consisting of clastic carbonate, foraminiferal tests and displaying a centrally located seam indicating the location of the original crack. Plain light; scale bar $=0.5 \mathrm{~mm}$. 
PLATE 13

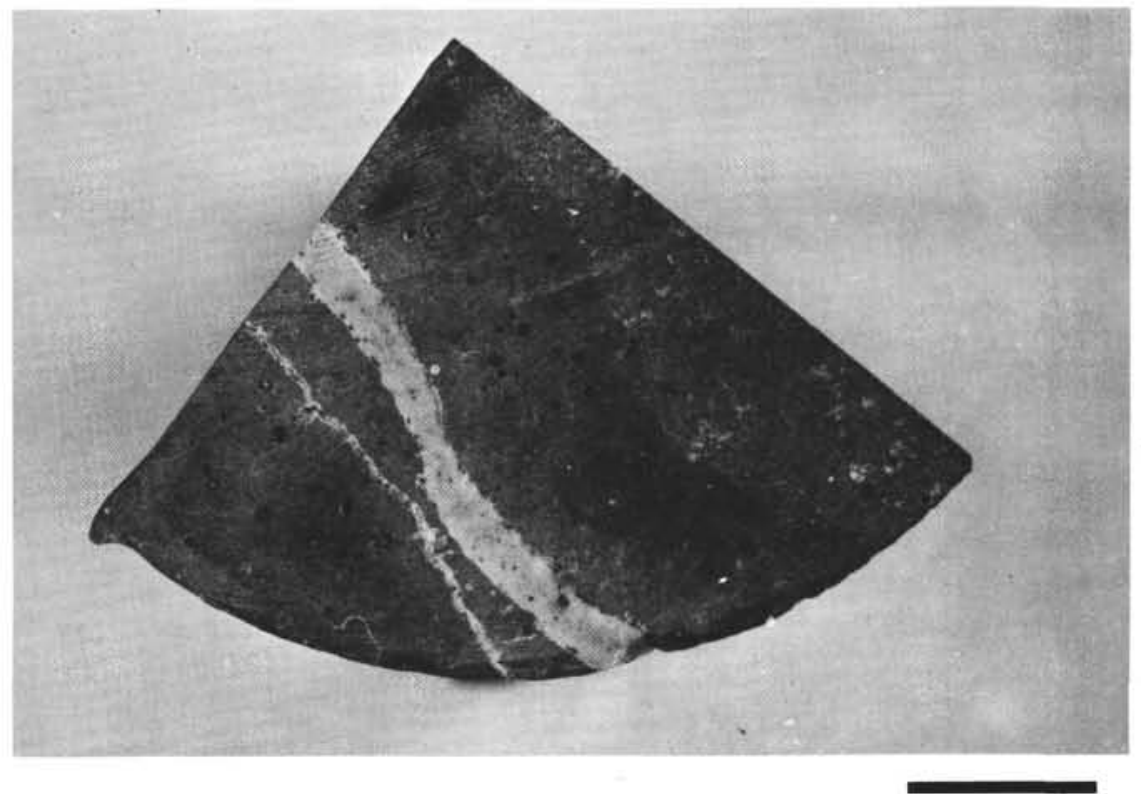

Sample 335-5-2, 24-26 cm. Clastic carbonate vein in basalt (described in Plate 12), exhibiting oxidation halo (dark band adjacent to vein). Scale bar $=1 \mathrm{~cm}$.

\section{PLATE 14}

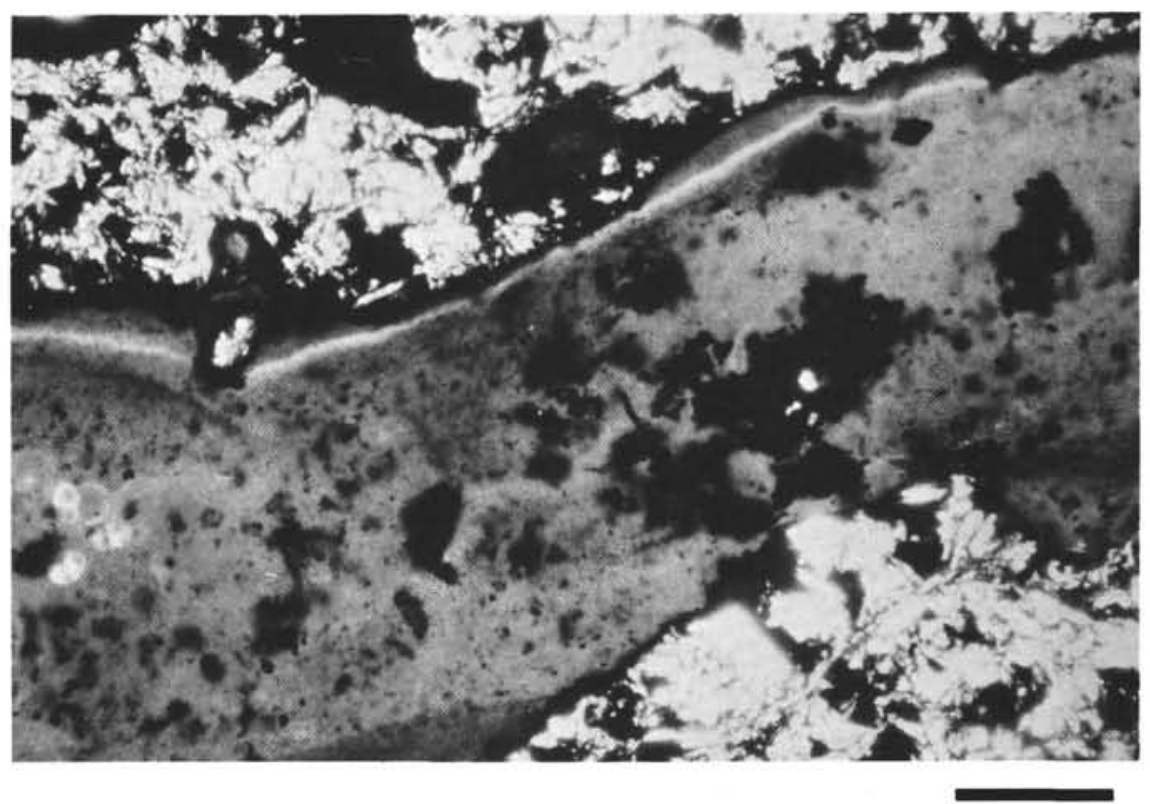

Sample 332B-37-2, $18-20 \mathrm{~cm}$. Clastic carbonate vein in basalt containing abundant highly altered, wall-rock fragments, and occasional foraminiferal tests. Many of these wall-rock fragments contain native copper (not visible) and some exhibit unaltered silicate cores. Plain light; scale bar $=0.5 \mathrm{~mm}$. 